\title{
Resultatbaseret statsstyring af lokal kernevelfærd
}

Marie Østergaard Møller, ph.d., lektor i statskundskab, Aalborg Universitet Vibeke Normann Andersen ph.d., analyse- og forskningschef, KORA, Det Nationale Institut for Kommuners og Regioners Analyse og Forskning

Resultatbaseret styring er et eksempel på en styring, der påvirker implementeringen af politik via en række specifikke politikredskaber. Artiklen diskuterer målanvendelse for at forklare, hvad der sker, når resultatbaseret styring møder velfærdsprofessionelle med et stort skøn i regelanvendelse overfor borgerne.

Resultatbaseret statsstyring og professionel praksis

Resultatbaseret styring er et eksempel på et sæt af politikredskaber, der bl.a. har til formål at påvirke de velfærdsprofessionelles adfærd og praksis, og som legitimeres ved et behov for at styrke kontrollen med de offentlige udgifter og understøtte kvaliteten i leveringen af offentlig service til borgerne (Lerborg 2013, 86-88).

Resultatbaseret styring anvendes internationalt fx til styring af bistandsmidler og nationalt i både den private og den offentlige sektor (se bl.a. Millar 2013; Mitchell 2014). I den offentlige sektor bruges resultatbaseret styring både til intern styring i staten, regioner og kommuner og til ekstern styring af fx kommunal kernevelfærd og til styring af eksterne leverandører af velfærd (Kristiansen 2014; Møller et al. 2016; Walker \& Andrews 2013).

Artiklen tager udgangspunkt $i$ et systematisk litteraturreview af statsstyring af lokal kernevelfærd på grundskole-, beskæftigelses- og det sociale område (Møller et al 2016). Reviewets overordnede konklusion er, at resultatbaseret statsstyring af lokal kernevelfærd ikke opnår de tilsigtede positive effekter for borgerne (ibid). Flere af reviewets studier peger på, at der opstår et modsætningsforhold mellem en politiskadministrativ og en professionel målforståelse under resultatbaseret styring, hvor den professionelle dømmekraft af, hvad der er problemet for en given borger, forringes eller i værste fald fortrænges af styreformens eksterne målkrav (Møller et al 2016: 65). 
Det er hensigten med analysen at bidrage til en mere dybdegående forståelse af mødet mellem resultatbaseret statsstyring af lokal kernevelfærd og professionel dømmekraft. Argumentet i nærværende artikel er, at resultatbaseret styring indeholder en målforståelse, der enten eksplicit eller implicit applicerer en forudindtaget problemforståelse af borgeren, som potentielt kan bidrage til at kortslutte den professionelle dømmekraft. Artiklen konkluderer, at der er en række logiske modsætninger mellem politisk målfastsættelse, administrativ målstyring, lokal oversættelse af mål til brug for konkret skønsudøvelse og professionel dømmekraft. Artiklen konkluderer, at disse modsætninger kan være med til at forklare de manglende positive effekter af resultatbaseret statsstyring af lokal kernevelfærd, som reviewet bl.a. finder.

Artiklens teoretiske afsæt er litteratur om mål- og resultatbaseret styring, klassifikation og problemfastsættelse, som de beskrives i tre forskellige litteraturer: 1) styrings- og forvaltningslitteratur om resultatbaseret styring, 2) markarbejderlitteratur om det professionelle skøn i en offentlig forvaltning og 3) professionslitteratur om indhold og betingelser for klassifikation og professionel dømmekraft. Selvom de tre litteraturer fremhæver forskellige aspekter ved levering af offentlig service, så er det analytisk frugtbart at forbinde dem her, fordi de deler en specifik interesse for hvordan generelle principper for viden og regler appliceres i praksis (Van Thiel \& Leeuw 2002; Smith 1995; Bouckaert \& Peters 2002; Tummers et al. 2015; Lipsky 1980; Grimen \& Molander 2008; Abbott 1988).50

Artiklen er organiseret i fire afsnit: Først et afsnit, der beskriver teori om resultatbaseret styring, derefter et afsnit, der beskriver de dominerende konklusioner i det systematiske litteraturreview. I tredje afsnit beskrives forvaltningslitteraturen om ikkeintenderede konsekvenser af målstyring, efterfulgt af en redegørelse af begreberne professionelt skøn, klassifikation og dømmekraft i frontlinjens professionelle praksis. I afsnit fire sammenlignes karakteren af styring, ledelse og problemidentifikation under henholdsvis resultatbaseret styring og i professionel praksis.

\section{Resultatbaseret styring}

Resultatbaseret styring er en administrationspolitisk styreform under New Public Management, der bygger på antagelserne 1) 'You can't manage what you don't measure' og 2) politikere, borgere og professionelle er rationelle beslutningstagere (Kravchuk \& Schack 1996). Det forventes, at beslutningstagerne reagerer rationelt på resultatinformation ved at reformere, nedskære eller fjerne indsatser, der måles som dårligt præsterende, mens de vil reagere med investering, vedligeholdelse og anerkendelse på gode præstationer. Måling spiller på den måde en afgørende rolle i en rationel organisationsledelse som resultatbaseret styring (Nielsen 2014), hvor dictum er, at der altid bør forandres, effektiviseres og effektmåles for at opnå en tæt og kontinuerlig resultatbaseret styring af leveringen af offentlig service (Lerborg 2013, 89). Styreformen adskiller sig på den måde fra andre styreformer ved at være særlig sårbar overfor fagprofessionel autonomi i 
den måde der leveres offentlig service på, fordi styreformen indbefatter en særlig høj grad af praksisintervention.

Der findes en lang række termer, der beskriver, hvad der kendetegner resultatbaseret styring, herunder begreber som målstyring og effektbaseret styring. I nærværende artikel sidestilles begreber, der kan inkluderes i følgende definition af styring og ledelse: "[begreber der] inkorporerer og ideelt set bruger de målte performance-informationer til at træffe beslutninger" (Van Dooren, Bouckaert \& Halligan 2015, 37), dvs. til begreber om en styreform, der kobler vidensindsamling med monitorering til styring og ledelse efter resultatmålinger (se Møller et al. 2016, 9).

Indenfor den samfundsvidenskabelige styrings- og ledelseslitteratur beskrives resultatbaseret styring som et redskab til at skabe positiv forandring til gavn for borgerne, såfremt en række betingelser er opfyldt, og centrale processer fungerer. De politiske og administrative aktører er væsentlige i styringskæden for at opnå resultater, fordi det er dem, der står i spidsen for at sikre den forventede borgereffekt. Der antages at være fire grundlæggende aktiviteter, der tilsammen gør, at resultatbaseret styring opnår effekt. Det drejer sig om 1) formulering af strategiske mål for en given indsats, 2) at indsatser og ressourcer skal organiseres, så de ønskede effekter kan opnås, 3) løbende monitorering og vurdering af præstationer og 4) at ledelsen træffer beslutninger på baggrund af data (Ejler et al. 2008).

I resultatbaseret styring er det beslutningstagernes ansvar at formulere konkrete målsætninger for, hvordan komplekse samfundsmæssige behov håndteres, herunder hvordan de bør og kan blive genstand for en politisk-administrativ intervention. Beslutningstagerne skal med andre ord tydeliggøre, ikke bare den politiske vision og de administrative rammer, men også problemets karakter, målgruppen for en given indsats, og hvad de anser for at være de ønskelige og hensigtsmæssige effekter (outcome) og langsigtede virkninger (impact) (Kristiansen 2014; Lerborg 2013). Dernæst skal indsatser og ressourcer organiseres i forhold til de ønskede effekter. Det skal fastlægges, hvilke indsatser, aktiviteter, produkter eller services, der skal benyttes til at opnå de ønskede effekter, altså overvejelser omkring indsatsens årsags-virkningsforhold. I resultatbaseret styring forudsættes det således, at der eksisterer en kausal sammenhæng mellem de aktiviteter, man måler på, og de effekter, som man forventer at opnå. Det centrale bliver derfor at få de ønskede effekter af indsatsen tydeligt beskrevet, så det forventede årsagsvirkningsforhold mellem indsats og effekter fremstår klart (Ejler et al. 2008; Eriksen 2008). For det tredje er løbende monitorering og vurdering af præstationer en forudsætning for at kunne styre efter effekter og dermed for at resultatbaseret styring forventes at få effekt. Det er gennem dokumentation (på baggrund af monitorering, dataindsamling og vurdering af præstationer), at det skal belyses, hvorvidt de politiske målsætninger opnås. De data, der indsamles, skal herefter bruges til at styre efter, og styringen antages således at virke bedst, hvis der er en klar kobling mellem de politiske målsætninger, de relevante indsatser og de forventede effekter. Det fjerde og sidste element i styringskæden er, at de data, der løbende indsamles, skal anvendes af ledelsen til at træffe beslutninger om, hvorvidt indsatsen skal korrigeres eller fortsættes uændret. Det er ledelsens 
ansvar at benytte data til styring af medarbejdere og samarbejdspartnere samt til justering af organisatoriske og ressourcemæssige forhold. Det er først, når ledelsen formår at benytte de data, der indsamles til at træffe beslutninger om indsatserne, at organisationen bevæger sig fra at måle resultaterne til at styre efter dem, dvs. flytter sig fra resultatmåling til egentlig resultatbaseret styring (se fx Bouckaert \& Halligan 2006).

Tværgående udfordringer med resultatbaseret statsstyring af lokal kernevelfærd

I en forskningsrapport baseret på et systematisk litteraturreview af resultatbaseret styringseffekter på undervisningsområdet, beskæftigelsesområdet og det sociale område, konkluderes det, at " resultatbaseret statsstyring har effekt på effektivitet og kvalitet for borgerne, men at den langt fra altid er positiv" (Møller et al. 2016, 64).

De klassificerede studier i reviewet viser at de forudsætninger, der kræves $\mathrm{i}$ implementeringen af resultatbaseret styring, ikke er til stede samtidig. Det gælder fx i formuleringen af, at mål skal være klare og transparente for at leve op til et kriterium om 'gode mål'. Her viser studierne, at det mange gange er svært for politikere og embedsmænd at opstille gode mål (Møller et al. 2016, 62). Derudover viser studier på tværs af de tre velfærdsområder, at der fokuseres på kortsigtede frem for på langsigtede resultater, samt at de "lette" borgere prioriteres frem for at bruge tid på borgere, der kræver en mere kompleks tilgang for at nå målet (Møller et al. 2016, 62).

Reviewet peger således på, at det kan være svært at få de basale forudsætninger vedrørende styring efter resultatmåling på plads. Det viser også, at resultatbaseret styring i praksis kan udfordres af, at der ikke træffes rationelle beslutninger på baggrund af den præstationsinformation, der måtte være indsamlet ganske validt. Her viser studier, hvorfor politikere og borgere kan misfortolke resultaterne, enten bevidst for egen vindings skyld eller ubevidst, fordi resultaterne formidles for komplekst, eller fordi der er strategiske interesserer på spil, der overskygger hensynet til målgruppen (Moynihan \& Hawes 2012; Olsen 2013; Barnow \& Smith 2004; Heinrich 1999; Soss et al. 2011; Askim 2007, Jansen 2008). Der er eksempler på, at professionelle prioriterer at løbe efter kortsigtede resultater, så man kan høste de lavthængende frugter fremfor at fokusere på at finde frem til den rette indsats for borgeren. Endelig viser reviewet også, at resultatbaseret styring risikerer at blive omdrejningspunkt for målfiksering og fastlæggelse af rutiner i arbejdsprocesserne frem for at blive brugt som redskab til refleksion og forbedring af den faglige omsætning af mål til praksis (Møller et al. 2016, 62). Der målfikseres $\mathrm{fx}$ ved at undervise i skoletest eller ved at prioritere lette borgere og fremme en tjeklisteadfærd frem for en reflekteret adfærd blandt de professionelle (Pires 2011).

På tværs af de inkluderede studier ser det således ud til, at det er svært at opstille statslige resultatmål, der ikke påvirker en etableret praksis negativt (Møller et al. 2016, 65). Flere af studierne finder for eksempel, at det er svært at afgøre, hvorvidt de anvendte måleredskaber rent faktisk også indfanger kerneydelsen på det givne velfærdsområde 
(Boyne \& Chen 2006; Barnow 2000; Heinrich 1999; Lindsay et al. 2014; Bovaird 2014; Meagher \& Healy 2003).

\begin{tabular}{l|l} 
Forudsætninger & Faktiske udfordringer \\
\hline 1. Klare mål & 1. Mange mål \\
\hline 2. Indsamling af valide data & $\begin{array}{l}\text { 2. Fokus på kortsigtede resultater og prioritering af "lette" bor- } \\
\text { gere }\end{array}$ \\
\hline 3. Resultatbeslutninger & 3. Politikere og borgere mistolker resultaterne \\
\hline 4. Redskab til refleksion & 4. Målfiksering og tjeklisteadfærd
\end{tabular}

Tabel 1. Konceptuelle forudsætninger og praktiske udfordringer i resultatbaseret statsstyring af lokal kernevelfærd. Kilde: Møller et al. 2016: 62

Reviewets fund er imidlertid og af gode grunde ikke nye, idet det sammenfatter eksisterende forskning om effekter af resultatbaseret statsstyring af lokal kernevelfærd på de udvalgte velfærdsområder fra 1995 og frem til 2014. Konklusionens rækkevidde er naturligvis betinget af de studier, som indgår i reviewet (se studier og studieselektion i Møller et al. 2016, 18f), men i modsætning til de fleste andre litteraturstudier, så er dette reviews studiepopulation ikke afgrænset metodisk eller teoretisk og indeholder således forskellige typer studier, som alle empirisk undersøger effekt af resultatbasereret statsstyring af lokal kernevelfærd (Møller et al. 2016, 19; 59). De meget forskelligartede studier identificerer imidlertid de samme typer af udfordringer og problemstillinger ved resultatbaseret statsstyring på tværs af de tre velfærdsområder. Ud fra et princip om datatriangulering peger lighederne på, at reviewets resultatet er mere sikkert end hvis det alene havde inkluderet studier fra ét område eller studier, der havde brugt bestemte metodiske og teoretiske tilgange (Møller et al. 2016, 18f).

Reviewets fund understøtter derudover eksisterende viden inden for den gren af forvaltningslitteraturen, der beskæftiger sig med ikke-intenderede konsekvenser af målstyring, samt litteratur om klassifikation og professionel dømmekraft, som vi udfolder og diskuterer i de følgende afsnit.

Ikke-intenderede konsekvenser af resultatbaseret styring

Resultatbaseret styring antages at kunne bidrage til at løse en række udfordringer i den offentlige sektor ved at specificere klare mål for det, som en offentlig organisation forventes at præstere (Kristiansen 2014). Men inden for forvaltningsforskning peges der også på, at resultatbaseret styring kan skabe problemer. En del af litteraturen om resultatbaseret styring omhandler netop ikke-intenderede effekter, dvs. konsekvenser af styreformen, som ingen har kalkuleret med eller ønsket skulle ske (Van Thiel \& Leeuw 2002).

Indledningsvis kan man sige, at denne del af forvaltningslitteraturen er skeptisk 
overfor, hvad man kan forvente af effekt fra en målstyringsform og en ledelsesstil, der skal implementeres oveni den offentlige sektors mange andre styringsformer, traditioner og systemer, som betyder at offentlige organisationer skal håndtere flere mål, der ofte konflikter (Boyne 2008; Boyne et al. 2005).

I litteraturen identificeres såvel teoretisk som empirisk en række ikkeintenderede konsekvenser, som har vist sig at påvirke implementering, herunder kvalitet og effektivitet $\mathrm{i}$ indsatserne over for borgerne. Der er for det første en dokumenteret tendens til, at antallet af indikatorer eskalerer under resultatbaseret styring (de Bruijn, de Bruijne \& Steenhuisen 2008). Hvis eksisterende indikatorer er utilstrækkelige, tilføjes nye mål og indikatorer. Målesystemerne bliver mere og mere omfattende frem for at sanere eksisterende mål og målesystemer. Årsagen synes at være, at intet enkelt målepunkt eller indikator kan indfange en sådan kompleksitet, ligesom der sjældent kan etableres en klar sammenhæng mellem mål, målinger og præstationer. Dette betegnes som mushrooming eller logic of escalation (de Bruijn, de Bruijne \& Steenhuisen 2008; Pollitt et al. 2010; Woelert 2015).

For det andet risikerer organisationer og dermed såvel ledere som fagprofessionelle at fokusere for ensidigt på at nå de mål, der er opstillet som del af et resultatbaseret styringssystem. Konsekvensen kan være, at de professionelle målfikserer så meget, at det skader kvaliteten og pålideligheden af de leverede indsatser til borgerne (Møller et al. 2016, 62), fordi det bliver det, som kan måles, eller de data, som er til rådighed, der kommer til at definere, hvad der er god kvalitet ved en indsats - og dermed det, som ledelse og medarbejdere er orienteret mod (Holm-Petersen, Wadmann \& Andersen 2015). Målfiksering beskrives andre steder som tunnelsyn, der henviser til en tendens til snævert at fokusere på synlige præstationer, som kan kvantificeres, hvilket risikerer at være på bekostning af de kvalitative aspekter ved en indsats (Van Thiel \& Leeuw 2002; Smith 1995; Bouckaert \& Peters 2002).

Når målfiksering dominerer, så viser studier i reviewet, at det er de svageste, der risikerer at få færrest ressourcer, opmærksomhed og investeringer fra det offentlige (se fx Andersen 2008). Svage grupper er ikke 'lette', hvilket forklarer hvorfor det er disse, der bliver frasorteret og 'parkeret' frem for grupper, der måske har relativt mindre gavn af en given indsats (Barnow \& Smith 2004; Cragg 1997). Det sker fx ved, at borgere, som har lettere ved at komme i beskæftigelse, prioriteres over borgere med større udfordringer på denne front.

For det tredje er tjeklisteadfærd en ikke-intenderet konsekvens. Her er det de svageste grupper, der bliver de mest sårbare, når det faglige skøn bliver til tjeklister (Ohemeng \& Mccall-Thomas 2013). Dette kan fremme rigiditet i det fagprofessionelle skøn og i deres arbejdsgange og føre til uønsket strategisk adfcerd (fx 'creaming') i forsøget på at leve op til de opstillede mål (Møller \& Stensöta 2017). Her viser et studie fra reviewet, hvordan velfærdsprofessionelle demotiveres i mødet med resultatbaseret styring. Studiet analyserer, hvorfor de ændrer adfærd i retning af tjeklisteadfærd, og hvordan de erstatter skønnet med en teknokratisk borgertilgang, dvs. en borgertilgang hvor regelopfyldelse bliver et mål i sig selv frem for et middel til at fremme et borgeroriente- 
ret formål (Dahler-Larsen \& Pihl-Thingvad 2014). Lovgivningens skærpede fokus på målopfyldelse kan fx bruges som et værn mod et helhedsorienteret borgerskøn, hvor medarbejderne ender med alene at forholde sig til, om lovens bogstav er overholdt og ikke til, om lovens formål, ånd eller intention indfris (Lipsky 1980; Tummers et al. 2015).

Anden forskning dokumenterer i tråd hermed, at professionelles reaktionsmønstre overfor resultatbaseret styring kan præges af negative afværgemekanismer som kommer til udtryk som problematiske prioriteringsstrategier af lette frem for trængende borgere og af stereotype klassifikationsstrategier til at afværge krydspres mellem regler og borgere (Berkel \& Knies 2016; Dias \& Maynard-Moody 2007; Møller 2016).

Mange af de forhold, som reviewet fremhæver som hæmmende faktorer, handler $i$ et eller andet omfang om, at det fagprofessionelle skøn erstattes af målfikseret tjeklisteadfcerd (Møller et al. 2016, 62). De empiriske fund tyder fx på, at forekomsten af resultatmål kan forhindre de fagprofessionelle $i$ at reflektere over deres problematisering af borgeren, når resultatmålet i sig selv peger på specifikke måder at forstå borgernes problemer på (se bl.a. Soss et al. 2011). I resultatbaseret styring anses politiskadministrative mål som standard og som uproblematiske styrepinde for hvilken indsats, en borger skal have. Relationen mellem fagprofessionel og borger er ikke en væsentlig del af resultatbaseret styring, og der kan derfor, som vi også fremhæver og redegør for i det følgende, opstå en uhensigtsmæssig kortslutning, eller hvad vi nedenfor vil diskutere som 'fejl-inferens' mellem problemidentifikation og borgerindsats.

\section{Professionel praksis under resultatbaseret styring}

Som resultaterne fra det systematiske review viste, så er der en tendens til at resultatbaseret styring opererer med mange antagelser om organisationers og individers adfærd, der kan kortslutte styringsforholdet mellem de velfærdsproducerende organisationer og de styrende politisk-administrative niveauer (Møller et al. 2016, 11; 62). Forskningen tyder på, at antagelsen om, at målfastsættelse kan ske som en ren politisk-administrativ øvelse, er problematisk, fordi medarbejdere på dette niveau meget sjældent har de rette kompetencer til at lave gode mål for praksis (se bl.a. Hunt \& Shackley 1999, 144). Bureaukrater er i høj grad styringskompetente opad i systemet og udformer således målene i overensstemmelse med de politisk-administrative behov. Udfordringen er imidlertid, at målene ikke nødvendigvis har en kobling til, hvordan arbejdet udføres i frontlinjens praksis. Studier viser her, at der opstår mange ikke tilsigtede handlinger og barrierer, hvis målfastsættelse isoleres fra den lokale virkelighed (Ohemeng \& Mccall-Thomas 2013; Pires 2011; Bovaird 2014; Lowe 2013). Ligesom forvaltningslitteraturen om ikke-intenderede styringseffekter peger frontlinjeforskning også på, at politisk rationalitet (herunder politiske beslutninger og politiske diskussioner) ikke kan isoleres til det centraladministrative niveau. Politisk rationalitet findes i alle kroge af samfundet (Lipsky $2010 ; 18)$. I samme tråd peger konklusionen i reviewet på en tendens til, at resultatbase- 
ret styring kræver mange ressourcer på administrationssiden, idet styreformen kræver en betydelig mængde administrative ressourcer for at kunne understøtte styreformens fire aktiviteter - målopstilling, målforankring, målmonitorering og målstyring.

\section{Viden og målforståelse i resultatbaseret styring}

Reviewet peger også på, at resultatbaseret styring forudsætter et bestemt effekt- og vidensbegreb (Ejler 2008; Kravchuk \& Schack 1996). I praksis forudsætter resultatbaseret styring en skalerbar viden, der kan kvantificeres og gøres til genstand for aggregerede analyser, mens kvalitative effektmålinger anses for kontekstuelle og fulde af 'støj' (et eksempel på denne tolkning af viden og rangering af viden kan fx findes hos Socialstyrelsen, der i 2013 har udgivet en guide til, hvordan man skal skalere sin viden under resultatbaseret styring). En umiddelbar konsekvens heraf er, at fagprofessionelles faglige ekspertise og erfaring ikke anvendes systematisk, fordi det ikke har en form eller et indhold, der umiddelbart kan opsamles i de standardiserede indsamlingsprocedurer, der karakteriserer velfærdsproduktion under resultatbaseret styring. Karakteren af den viden, der indsamles i resultatbaseret styring hænger naturligvis sammen med, at et væsentligt element i styreformen er, at man er enige om ikke blot hvilke mål, der skal styres efter, men også hvilke typer af beslutninger, der skal kunne træffes på baggrund af den indsamlede viden (Kristiansen 2014). Når staten resultatstyrer, så betyder det, at målene bestemmes centralt af de politiske beslutningstagere og deres embedsmænd på afstand fra de borgere, målene retter sig mod og på afstand af de professionelle, der skal udøve indsatserne i praksis. Stedbunden, kontekstuel viden bliver for kompleks og uregerlig i bogstaveligste forstand, fordi den type viden, der opsamles og anvendes på en eller anden måde skal indgå i en styrbar monitorering af indsatser og professionel adfærd. Typiske eksempler på monitoreringsduelig viden er viden, der er indsamlet via faste indsamlingsstrategier så som nationale skoletests, spørgeskemabesvarelser og effektklassifikationer, mens eksempler på kontekstuel viden er lægejournaler, elevplaner og børneundersøgelser.

\section{Afværgemekanismer og professionel dømmekraft}

Ligesom i forvaltningslitteraturen om de ikke-intenderede konsekvenser er man i litteraturen om frontlinjeadfærd og nærbureaukrati optaget af at beskrive, hvornår styring kan virke inkompatibel med udøvelse af et professionelt skøn (Lipsky 2010). Argumentet er her, at det ikke er politikerne, der beslutter ordlyden af politikken eller de embedsmænd, der udformer og beskriver dens procedurer, der er de reelle politiske beslutningstagere. Det er de medarbejdere, der på baggrund af et fagprofessionelt skøn træffer beslutninger på borgernes vegne om, hvad der skal gøres, hvornår og hvorfor (Lipsky 2010, 3). 
Der er overordnet set to forståelser af det fagprofessionelle skøn: en forståelse, der ser skønnet som noget, der skal indskrænkes for at undgå, at de fagprofessionelles subjektive meninger om henholdsvis borgerne og den politik, de skal føre ud i livet, resulterer i ulig borgerbehandling (Brehm \& Gates 1999; May \& Winter 2009). En anden forståelse ser det fagprofessionelle skøn som en forudsætning for en præcis og lige levering af offentlig ydelse (Grimen \& Molander 2008; Lipsky 2010). Her ser man ikke indholdet af skønnet som bestemt af subjektive meninger, men som dækkende over fagprofessionel viden og erfaring, som et nødvendigt element $i$ at kunne håndtere borgernes situationer, som altid er mere eller mindre komplekse og ikke meningsfuldt lader sig reducere til målingsarbejde af den karakter, der fx kræves under resultatbaseret statsstyring af lokal kernevelfærdsskabelse (se bl.a. Bovaird 2014).

Argumentet for at forstå det professionelle skøn som et uundgåeligt element i leveringen af offentlig service er, at menneskelige forhold har forskellig betydning for forskellige mennesker, hvorfor de fagprofessionelle, der omsætter offentlig politik i mødet med borgerne, må være i stand til at forstå, forklare og beskrive, hvad der skal til $i$ det enkelte tilfcelde for, at en politik kan lykkes i praksis (Lipsky 2010,15).

I professionssociologien interesserer man sig på lignende vis for det fagprofessionelle skøn som en refleksiv, diagnostisk praksis (Abbott 1988) og dvs. som en praksis, der har en kognitiv og epistemologisk karakter (Grimen \& Molander 2008). Her understreges ligeledes en forståelse af det fagprofessionelle skøn som vurdering, der ikke kan reduceres til en eksplicit regel. Et fagprofessionelt skøn indeholder valget mellem flere muligheder og må ifølge Grimen og Molander (2008) således forstås som en kognitiv praksis, hvor der skal ræsonneres for at vælge mellem flere mulige fortolkninger af 'sagen’ (Møller 2016). Karakteren af lovgivning, retningslinjer, målstyring og skolastisk viden om årsags-virkningssammenhænge, herunder faglige rutiner og personlig erfaring, der kognitivt set bringes i anvendelse af den professionelle i mødet med en 'sag', er i denne optik nok noget, der strukturerer, men som aldrig kan afgøre indholdet af en konkret vurdering af en patient, en arbejdsløs eller en borgers behov for offentlige service (Wilensky 1964; Lipsky 2010; se bl.a. Epp \& Maynard-Moodys (2014) begreb om 'inhabited institutions' for uddybning af skønnet som kognitiv praksis).

Forståelsen af det fagprofessionelle skøn som en forudsætning og ikke en hæmsko for ordentlig og effektiv levering af offentlig service kendetegner også den del af professionslitteraturen, der interesserer sig for dømmekraft. Her er der enighed om, at et kerneelement i velfærdsprofessionel praksis og skønsudøvelse er evnen til at udøve en fagprofessionel dømmekraft over for borgerne (Grimen \& Molander 2008; Freidson 2001; Abbott 1988; Schön 1983; Sciulli 2009). Her er man optaget af spørgsmålet om, hvad der adskiller fagprofessionel dømmekraft fra en almindelig lægmandsbetragtning på et givent problem, fx sygdom, læringsvanskeligheder eller ulyksalighed. Fokus er på at betragte det fagprofessionelle skøn som et særligt klassifikationshåndværk, der forudsætter social interaktion fx mellem en læge og en patient, mellem en pædagog og et barn eller mellem en bibliotekar og en borger for at kunne klassificere vedkommendes behov og dermed skønne, hvad der her skal 'doseres' af medicin, omsorg eller romaner 
for at 'ramme' rigtigt. Det fagprofessionelle skøn er således en kapacitet, der kræver personligt engagement, social interaktion og refleksion, hvilket dog ikke må forveksles med en privat bedømmelse af, hvorfor en given indsats fremhæves over en anden (Abbott 1988, 52). Det fagprofessionelle skøn er således en dømmekraft, der ikke kan reduceres til tjeklister, eller til eksternt bestemt målstyring, der opererer per automatik og uden en eksplicit individbunden referenceramme (Abbott 1988; Anderschou \& Harrits 2014).

Den del af professionsteorien, der er optaget af sammenhænge mellem fagprofessionel dømmekraft, styring og ledelse, er primært fokuseret på at forstå forholdet mellem subjektive og fagprofessionelle vurderinger og ikke mindst af, hvad der kvalificerer fagprofessionel dømmekraft (Grimen \& Molander 2008; Sciulli 2009). Her peges på en evne til at kunne omsætte videnskabelig viden til praktisk handling (Brante 2011) og på en evne til vurdere, hvordan formålet med regler oversættes til noget, der kan give mening i borgernes liv. Endelig peger Schön på, at fagprofessionel dømmekraft udtrykkes i en evne til at hæve sig op over sin praksis og reflektere over den i en generel, abstrakt, analytisk sammenhæng (Schön 1983).

Abbott siger mere præcist om fagprofessionelt arbejde, at det er defineret ved et miks af objektive og subjektive 'kvaliteter' (Abbott 1988, 40). De objektive kvaliteter vedrører teoretisk og generel viden om problemer og behandlinger, dvs. om forskellige skolastiske klassifikationssystemer, mens de subjektive kvaliteter vedrører evnen til at forstå det konkrete individs særlige behov og symptomer i lyset af en generel viden. Mere præcist siger Abbott, at de subjektive kvaliteter består af evnen og retten til at klassificere et problem, til at ræsonnere over det og til at handle på det eller formuleret $\mathrm{i}$ mere formelle vendinger til at diagnosticere, inferere (udlede) og behandle (Abbott 1988, 40). Teoretisk set er det således disse tre handlinger, der tilsammen definerer den fagprofessionelle praksis, og som afgør, om en dømmekraft udøves fagprofessionelt eller automatiseret.

I en bredere sammenhæng kan diagnose, behandling og inferens forstås som problemidentifikation, problemintervention og professionel ræsonnement eller som klassifikation. Pointen hos Abbot er, at ingen af de tre kognitive praksisser kan objektiviseres fuldstændig, dvs. hverken identifikation af problemet eller intervention kan udledes fra objektive kvaliteter alene, ligesom de heller ikke kan være en ren subjektiv øvelse, dvs. udledes fra det konkrete tilfælde (møde med borgeren) alene. Den fagprofessionelle dømmekraft er i en vis forstand abduktiv, dvs. at den fagprofessionelle bruger sin generelle viden (viden om de objektive kvaliteter) og erfaring med lignende typer af eksempler til at spore og til at 'se' borgerens unikke behov og problem, ligesom det er identifikationen af det esoteriske eller det unikke, der hele tiden bruges til at teste den generelle forståelse af en given objektivt beskrevet årsags-virkningssammenhæng. Først herefter kan den fagprofessionelle foretage det, Abbott kalder klassifikation, dvs. indplaceringen af det enkelte tilfælde i den relevante kategori med henblik på at lave en endelig identifikation af borgerens problem og behandling. Det betyder, at fagprofessionel dømmekraft forudsætter subjektive kvaliteter, der er svære at bruge uden en vis 
grad af autonomi til at bestemme, udlede og identificere den mest præcise klassifikation af borgeren (Abbott 1988, 44). Meget enkelt kan man sige, at 'vejen' til fagprofessionel behandlingssucces går gennem inferens. Når den fagprofessionelle lader de objektive kvaliteter (over)determinere vurderingen af borgerens konkrete problem, er det ifølge Abbott et eksempel på svag inferens, mens stærk inferens forekommer, når den fagprofessionelle (over)determinerer vurderingen af borgerens konkrete problem uden reference til de objektive kriterier, der definerer en given profession og dens standarder (Abbott 1988, 44).

Fagprofessionel inferens under resultatbaseret styring

De ikke-intenderede konsekvenser under resultatbaseret styring, der vedrører de fagprofessionelles tjeklisteadfærd og tunnelsyn, kan med Abbotts klassifikationsteori forstås som en ubalance mellem for svag eller for stærk fagprofessionel inferens dvs. en ubalanceret kognitiv kobling mellem problem- og indsatsidentifikation, hvor indsatser enten appliceres for generelt på målgruppens borgere og deres problemer (svag inferens), eller hvor der 'opfindes' en ny behandling til hver enkelt borger, der mødes af en fagprofessionel (stærk inferens). Med Abbotts egne ord: "For lidt inferens er en velkendt del af det større fænomen rutineadfærd" (Abbott 1988, 51, egen oversættelse). Dvs. rutineadfærd, eller hvad reviewet referer til som tjeklisteadfærd, opstår, når der anvendes for svag inferens, dvs. når der ingen forbindelseslinjer skabes via et subjektivt fagligt ræsonnement eller, hvor der kategorisk afvises, at der kan etableres en forbindelseslinje mellem borgerens problem og en generel viden og dvs. hvor koblingen til de objektive kvaliteter kortsluttes. I begge tilfælde kan det i følge Abbott betyde, at det fagprofessionelle ræsonnement, dvs. den udledende kobling, der sikrer, at det giver mening at anvende en given indsats overfor en konkret borger, tilsidesættes. Fagprofessionel viden kan med begrebet om klassifikation således præciseres til at komme til udtryk som en særlig kognitiv praksis, eller ræsonnementet, der skaber mellemregningen mellem diagnose og indsats $f x$ af en socialarbejders problemidentifikation af et barns behov for en psykologisk indsats eller en hjemmestøtteordning. Under resultatbaseret styring bliver der opstillet mål for fagprofessionel praksis på det politisk/administrative niveau, hvilket ifølge Abbotts begreb om inferens kan indsnævre det fagprofessionelle vurderingsrum og i værste fald erstatte et fagprofessionelt skøn med rutineadfærd. Det sker også fordi forholdet mellem diagnose og behandling i praksis ofte foregår samtidigt og ikke som i en adskilt lineær proces. Diagnosen stilles/ændres/forfines, idet den fagprofessionelle prøver en specifik behandling af og ikke kun forud for interventionen. Den professionelle praksis er årsagsstyret, hvilket betyder, at målet med en indsats kan skifte karakter mange gange under behandlingen af borgeren, netop fordi diagnosen eller identifikationen af problemet skifter. Det beskriver en praksis, der meget let kan komme i konflikt med et effekt- og resultatstyringsprincip, hvor mål og effekt er noget der 'bestilles udefra', og, som vi beskriver i det følgende, er at sammenligne med statiske kon- 
trakter, der ikke fungerer særlig smidigt som diagnostiske redskaber til problemløsning (Abbott 1988, 48).

Sammenlignes styringslitteraturen med professionslitteraturens forståelse af sammenhængen mellem mål og indsats, bliver det ligeledes tydeligt, hvordan de adskiller sig fra hinanden i spørgsmålet om, hvem der skal identificere og formulere målene, og hvordan man skal styre efter dem i praksis. Styringslitteraturens målforståelse fastlåser både problemidentifikation og indsats til eksternt bestemte mål og fremmer således sandsynligheden for, at den fagprofessionelle ikke reflekterer over, hvad der er den rette behandling for borgeren. Den stærke kobling mellem mål og indsats kan fjerne fokus fra en kobling mellem generel viden og konkret problem og altså for den mellemregning, der ifølge Abbott sikrer, at patienten diagnosticeres, dvs. problemidentificeres og behandles korrekt. Forskellen mellem styring, mål, skøn og problemidentifikation i resultatbaseret styring og professionel praksis kan vi skematisk opsummere på følgende måde:

\begin{tabular}{l|l|l} 
& Resultatbaseret styring & Professionel praksis \\
\hline Styringsprincip & Effekt- og resultatstyring & Årsagsstyring \\
\hline Mål & Politisk-administrativ & Diagnostisk \\
\hline Skøn & Subjektiv støj & Refleksiv inferens \\
\hline Problemidentifikation & Målafledt & Skønsudledt
\end{tabular}

Tabel 2. Resultatbaseret styring og professionel praksis

Kvaliteten i styring af kernevelfærd afhænger ifølge Abbotts logik af de fagprofessionelles kognitive kapacitet til at lave 'tilpas' inferens mellem generel viden, problemidentifikation og indsats og dvs. afhænger af (styrings- og ledelsesmæssig) mulighed for, at de fagprofessionelle kan bruge professionens generelle viden om årsager til problemer og til at kunne bruge de indsatser, der anses for plausible behandlinger. Kvaliteten vil derfor også afhænge af den diagnostiske praksis og den heraf udledte indsats, hvilket indenfor resultatbaseret styring vil sige af de politisk-administrative mål, der formuleres og den effekt, der styres efter, mens det i fagprofessionel praksis henviser til de klassifikationer, der også beskriver hvilke årsager, man forstår og styrer efter. I modsætning til fagprofessionel praksis vælges indsatser og dermed også diagnoserne på forhånd i resultatbaseret styring, hvor det også forudsættes apriorisk, at implementering af specifikke indsatser vil føre til specifikke effekter (Ejler et al. 2008). Den mellemregning mellem mål og effekt, som bl.a. Abbott peger på, udgøres af den fagprofessionelle dømmekraft, fjernes under resultatbaseret styring. Det diagnostiske råderum bliver således reduceret af målet, ligesom effekten reduceres til at blive en mere eller mindre succesfuld implementering af specifikke forudbestemte indsatser. Hvis målet således er prædefineret, så bliver også selve diagnosen eller problemidentifikationen bestemt uden et fagprofessionelt skøn og uden et fagprofessionelt ræsonnement for, hvorfor én og ikke en anden indsats iværksættes overfor borgeren. 


\section{Konklusion}

Artiklen har udfoldet argumentet, at resultatbaseret styring indeholder en målforståelse, der kortslutter den fagprofessionelle dømmekraft, og at det er denne kortslutning, der kan være en medvirkende årsag til nogle af de manglende positive effekter af resultatbaseret statsstyring af lokal kernevelfærd, som har været genstand for analyse og teoretisk diskussion i nærværende artikel. Mere præcist har målet med analysen i denne artikel været at undersøge, hvad det er i resultatbaseret styring, der støder sammen med professionel praksis. Vi har trukket på forvaltningslitteratur om ikke-intenderede konsekvenser af målstyring, frontlinje-, og professionsteori omkring formulering af mål og problemidentifikation for at kunne pege på, hvorfor brugen af centralt fastsatte resultatmål kan skabe konflikt og modstand i styringsrelationen mellem stat og borger. Idet politisk rationalitet, i modsætning til hvad man antager i resultatbaseret styring, sjældent kun udspiller sig på det centrale politisk-administrative niveau fx i staten, vil der let kunne opstå kamp om operationalisering og oversættelse af de centralt fastlagte mål flere steder i den offentlige forvaltning. Alt andet lige risikerer dette at bidrage til målekompleksitet i oversættelserne fra centraladministrative målbeskrivelser til de lokale, borgernære forvaltninger. Derudover vil en stigende målekompleksitet kunne komme til at forstærke et behov for kontrol af praksis, idet det her bliver tydeligt, at målene er politiske. Alle aktører vil sikre sig, at det bliver deres målforståelse, der definerer indsats og de fagprofessionelles adfærd, hvilket igen kan føre til en reaktion som målfiksering, hvor fagprofessionelle og medarbejdere med måleansvar fikserer deres fokus på de målbare aspekter ved deres arbejde og derved fjerner fokus fra dets overordnede formål.

Analysen viste også, at idet et mål også altid er et ønske om en effekt, og idet en effekt skal afspejle den tilstand en borger forventes at være i efter en indsats, så forventes der at være en logisk sammenhæng mellem mål og effekt. Men ifølge professionsteorien, så afhænger hvilken tilstand, en borger kan befinde sig i efter en indsats, af, at den fagprofessionelle har ræsonneret sig frem til den 'rette' klassifikation af problemet, og dvs. af, at den fagprofessionelle er fri af eksterne målbeskrivelser til at vurdere, hvad der er den rette prisme at betragte borgeren med. Problemidentifikation, problemomfang og problemkarakter er således et resultat af en nuanceret, kompliceret og konkret vurdering, der både har objektive og subjektive kvaliteter. Med udgangspunkt i Abbotts begreb om klassifikation understreges den kognitive evne til at inferere mellem det esoterisk konkrete og det abstrakte generelle som kernen i det professionelle arbejde (Abbott 1988; Anderschous \& Harrits 2014; Harrits \& Møller 2016; Møller 2016; Grimen \& Molander 2008). Når mål defineres politisk-administrativt 'udefra' erstattes denne evne til professionel ræsonnement af rutine- eller tjeklisteadfærd.

Fremadrettet kunne det være interessant at undersøge ovenstående forklaring yderligere. I en netop udgivet forskningsartikel finder frontlinjeforskere, at offentlige ledere har en tendens til at understøtte de professionelles prioriteringsstrategier, uanset, at de dermed kan komme til at bryde med princippet om, at alle skal behandles lige for loven (Tummers 2017, 162.). Det peger på, at offentlige ledere ønsker at skærme de 
professionelle mod autonomitab og dermed mod prædefinerede mål udefra for at fastholde deres medarbejderes evne til at udøve professionel dømmekraft i mødet med borgerne, ligesom det mere implicit peger på, at afstand mellem styring og praksis har en betydning for kvaliteten af levering af offentlig service til borgerne.

Litteratur

Abbott, A. (1988). The system of professions: an essay on the division of expert labor. Chicago: University of Chicago Press.

Anderschou, S. B. and Harrits, G. S. (2014). Mellem viden og styring: En analyse af teknologiske forandringer i relationen mellem stat og profession. In: G. S. Harrits, M.

B. Johansen, J. E. Kristensen, L. T. Larsen and S. G. Olesen, ed., Professioner Under Pres. Systime Academic.

Andersen, S. C. (2008). The impact of public management reforms on student performance in Danish schools. Public Administration, vol. 86(2), pp. 541-558.

Askim, J. (2007). How do politicians use performance information? An analysis of the Norwegian local government experience. International Review of Administrative Sciences, vol. 73(3), pp. 453-472.

Barnow, B. (2000). Exploring the relationship between performance management and program impact: A case study of the Job Training Partnership Act. Journal of Policy Analysis and Management, vol. 19(1), pp. 118-141.

Barnow, B. S. and Smith, J. A. (2004). Performance Management of U.S. Job Training Programs: Lessons from the Job Training Partnership Act. Public Finance and Management, vol. 4(3), pp. 247-287.

Berkel, R. and Knies, E. (2016). Performance Management, Caseloads and the Frontline Provision of Social Services. Social Policy \& Administration, vol. 50(1), pp. 5978.

Bovaird, T. (2014). Attributing Outcomes to Social Policy Interventions - 'Gold Standard' or 'Fool's Gold' in Public Policy and Management?. Social Policy and Administration, vol. 48(1), pp. 1-23.

Bouckaert, G. and Peters, B. G. (2002). Performance Measurement and management. The Achilles' Heel in Administrative Modernization. Public Performance \& Management Review, vol. 25(4), pp. 359-362.

Bouckaert, G. and Halligan, J. (2006). Performance and Performance Measurement. In: G. B. Peters and J. Pierre, ed., Handbook of Public Policy, 1.st ed. London: SAGE Publications, pp. 443-459. 
Boyne, G. A. and Chen, A. A. (2006). Performance Targets and Public Service Improvement. Journal of Public Administration Research and Theory, vol. 17(3), pp. 455-477.

Boyne, G. A. (2008). What is public service improvement?. Public Administration, vol. 81(2), pp. 211-227.

Boyne, G. A., Meier, K. J., O’Toole, L. J. and Walker, R. M. (2005). Where next? Research directions on performance in public organizations. Journal of Public Administration Research and Theory, vol. 15(4), pp. 633-639.

Brehm, J. and Gates, S. (1999). Working, shirking, and sabotage: Bureaucratic response to a democratic public. Ann Arbor: University of Michigan Press.

Cragg, M. (1997). Performance Incentives in the Public Sector: Evidence from the Job Training Partnership Act. Journal of Law, Economics, and Organization, vol. 13(1), pp. 147-168.

Dahler-Larsen, P. and Pihl-Thingvad, S. (2014). How performance management may lead to stress: a group-level analysis of performance measurement and employees' stress. Danish journal of management \& business, vol. 78(3/4), pp. 46-61.

de Bruijn, H., de Bruijne, M. and Steenhuisen, B. (2008). Managing infrastructure Performance. An Empirical Study on the Use of Performance Management Systems in Two Network Industries. Competition and Regulation in Network Industries, vol. 9(1), pp. 75-91.

Dias, J. J. and Maynard-Moody, S. (2007). For-Profit Welfare: Contracts, Conflicts, and the Performance Paradox. Journal of Public Administration Research and Theory, vol. 17(2), pp. 189-211.

Ejler, N., Seiding, H. R., Bojsen, D. S., Nielsen, S. B. and Ludvigsen, F.,(2008). Når måling giver mening. Resultbaseret styring og dansk velfcerdspolitik i forvandling. København: Jurist- og Økonomforbundets Forlag.

Epp, C. R., Maynard-Moody, S. and Haider-Markel, D. P. (2014). Pulled over: How police stops define race and citizenship. Chicago: University of Chicago Press.

Eriksen, M. (2008). Den logiske model - et varktøj til at planlagge, gennemføre og evaluere sociale indsatser. Aarhus: KREVI.

Freidson, E. (2001). Professionalism: the third logic. Cambridge: Polity.

Grimen, H. (2008). Profesjon og skjønn. In: A. Molander and L. I. Terum, ed., Profesjonsstudier, Oslo: Universitetsforlage.

Harrits, G. S. and Møller, M. Ø. (2016). Forebyggelse og bekymring I professionel praksis. København: Hans Reitzels Forlag.

Heinrich, C. J. (1999). Do Government Bureaucrats Make Effective Use of Performance Management Information?. Journal of Public Administration Research and Theory: J-PART, vol. 9(3), pp. 363-393.

Holm-Petersen, C., Wadmann S. and Andersen N. B. V. (2015). Styringsreview på hospitalsområdet. København: KORA - Kommunernes og Regionernes Forskningsog Analyseinstitut. 
Hood, C. and Dixon, R. (2015). A Government that Works Better and Costs Less?. Oxford: Oxford University Press.

Hunt, J. and Shackley, S. (1999). Reconceiving science and policy: academic, fiducial and bureaucratic knowledge. Minerva, vol. 37(2), pp. 141-164.

Jansen, E. P. (2008). New public management: perspectives on performance and the use of performance information. Financial Accountability \& Management, vol. 24(2), pp. 169- 191.

Kaspersen, L. B and Knudsen, J. N. (2015). Ledelseskrise i konkurrencestaten. København: Hans Reitzels Forlag.

Kravchuk, R. and Schack, R. (1996). Designing effective performance-measurement systems under the Government Performance and Results Act of 1993. Public Administration Review, vol. 56(4), pp. 348-358.

Kristiansen, M. B., ed. (2014). Resultatstyring i den offentlige sektor. København: Jurist- og Økonomiforbundets Forlag.

Lerborg, L. (2013). Styringsparadigmer i den offentlige sektor, 3rd ed. København: Jurist- og Økonomforbundets Forlag.

Lindsay, C., Osborne, S. P. and Bond, S. (2014). The 'New Public Governance' and Employability Services in an Era of Crisis: Challenges for Third Sector Organizations in Scotland. Public Administration, vol. 92(1), pp. 192-207.

Lipsky, M. (2010). Street-Level Bureaucracy - Dilemmas of the Individual in Public Services. 30th Anniversary, Expanded Edition. New York: Russell Sage Foundation.

Lowe, T. (2013). New development: The paradox of outcomes - the more we measure, the less we understand. Public Money \& Management, vol. 33(3), pp. 213-216.

May, P. J. and Winter, S. C. (2009). Politicians, managers, and street-level bureaucrats: Influences on policy implementation. Journal of Public Administration Research and Theory, vol. 19(3), pp. 453-476.

Meagher, G. and Healy, K. (2003). Caring, controlling, contracting and counting: Governments and non-profits in community services. Australian Journal of Public Administration, vol. 62(3), pp. 40-51.

Millar, H. (2013). Comparing accountability relationships between governments and non-state actors in Canadian and European international development policy', Canadian Public Administration, vol. 56(2), pp. 252-269.

Mitchell, G. E. (2014). Why will we ever learn? Measurement and evaluation in international development NGOs. Public Performance \& Management Review, vol. 37(4), pp. 605-631.

Moynihan, D. P. and Hawes, D. P. (2012). Responsiveness to Reform Values: The Influence of the Environment on Performance Information Use. Public Administration Review, vol. 72, pp. 95-105.

Møller, M. Ø. and Stensöta, H. O. (2017). Welfare State Regimens and Caseworkers' Problem Explanation, Administration \& Society, DOI: $10.1177 / 0095399717700224$, pp. 1-29 
Møller, M. Ø., Iversen, K. and Andersen, V. N. (2016). Review af resultatbaseret styring. Resultatbaseret styring på grundskole-, beskaftigelses- og socialområdet. København: København: KORA - Kommunernes og Regionernes Forsknings- og Analyseinstitut.

Møller, M. Ø. (2016). “She isn’t Someone I Associate with Pension”-a Vignette Study of Professional Reasoning. Professions and Professionalism, vol. 6(1), pp. 1-20.

Nielsen, P. A. (2014). Learning from Performance Feedback: Performance Information, Aspiration Levels, and Managerial Priorities. Public Administration, vol. 92(1), pp. 142-160.

Ohemeng, F. and Mccall-Thomas, E. (2013). Performance management and "undesirable" organizational behaviour: Standardized testing in Ontario schools. Canadian Public Administration-Administration Publique Du Canada, vol. 56(3), pp. 456477.

Olsen, A. L. (2013). Leftmost-Digit-Bias in an Enumerated Public Sector? An Experiment on Citizens' Judgment of Performance Information. Judgment and Decision Making, vol. 8(3), pp. 365-371.

Pires, R. R. C. (2011). Beyond the Fear of Discretion: Flexibility, Performance, and Accountability in the Management of Regulatory Bureaucracies. Regulation and Governance, vol. 5(1), pp. 43-69.

Pollitt, C., Harrison, S., Dowswell, G., Jerak-Zuiderent, S. and Bal, R. (2010). Performance Regimes in Health Care: Institutions, Critical Junctures and the Logic of Escalation in England and the Netherlands. Evaluation, vol. 16(1), pp.

Schön, D. A. (1983). The reflective practitioner: how professionals think in action. New York: Basic Books.

Sciulli, D. (2009). Professions in civil society and the state: invariant foundations and consequences. Leiden: Brill.

Smith, P. (1995). On the unintended consequences of publishing performance data in the public sector. International Journal of Public Administration, vol. 18(2), pp. 277-310.

Socialstyrelsen. (2013). Viden til gavn. Politik for udvikling og anvendelse af evidens. Odense: Socialstyrelsen.

Soss, J., Fording, R., and Schram, S. F. (2011). The Organization of Discipline: From Performance Management to Perversity and Punishment. Journal of Public Administration Research and Theory, vol. 21, pp. I203-I232.

Tummers, L. L., Bekkers, V., Vink, E. and Musheno, M. (2015). Coping during public service delivery: A conceptualization and systematic review of the literature. Journal of Public Administration Research and Theory, vol. 25(4), pp. 10991126.

Tummers, L. (2017). The Relationship Between Coping and Job Performance. Journal of Public Administration Research and Theory, vol. 27(1), pp. 150-162.

van Dooren, W., Bouckaert, G. and Halligan, J. (2015). Performance management in the public sector. London; New York: Routledge. 
Van Thiel, S. and Leeuw, F. (2002). The Performance Paradox in the Public Sector. Public Performance \& Management Review, vol. 25(3), pp. 267-281.

Walker, R. M. and Andrews, R. (2013). Local government management and performance: a review of evidence. Journal of Public Administration Research and Theory, vol. 25(1), pp. 101-133.

Wilensky, H. L. (1964). The Professionalization of Everyone?. American Journal of Sociology, vol 70(2), pp. 137-158.

Woelert, P. (2015). The 'logic of escalation' in performance measurement: An analysis of the dynamics of a research evaluation system. Policy and Society, vol. 34(1), pp. 75-85. 